\title{
A new Middle-Upper Jurassic succession on Hold with Hope, North-East Greenland
}

\author{
Henrik Vosgerau, Michael Larsen, Stefan Piasecki and Jens Therkelsen
}

\begin{abstract}
A succession of marine, Jurassic sediments was recently discovered on Hold with Hope, NorthEast Greenland. The discovery shows that the area was covered by the sea during Middle-Late Jurassic transgressive events and thus adds to the understanding of the palaeogeography of the area. The Jurassic succession on northern Hold with Hope is exposed in the hangingwalls of small fault blocks formed by rifting in Late Jurassic - Early Cretaceous times. It unconformably overlies Lower Triassic siltstones and sandstones and is overlain by Lower Cretaceous coarsegrained sandstones with an angular unconformity. The succession is up to $360 \mathrm{~m}$ thick and includes sandstones of the Lower-Upper Callovian Pelion and Middle-Upper Oxfordian Payer Dal Formations (Vardekløft Group) and heteroliths and mudstones of the Upper Oxfordian Lower Kimmeridgian Bernbjerg Formation (Hall Bredning Group). The Pelion Formation includes the new Spath Plateau Member (defined herein).

The palaeogeographic setting was a narrow rift-controlled embayment along the western margin of the rifted Jurassic seaway between Greenland and Norway. It was open to marine circulation to the south as indicated by the distribution and lateral facies variations and a dominant south-westwards marine palaeocurrent direction. The Pelion and Payer Dal Formations represent upper shoreface and tidally influenced delta deposits formed by the migration of dunes in distributary channels and mouthbars over the delta front. The boundary between the two formations is unconformable and represents a Late Callovian - Middle Oxfordian hiatus. It is interpreted to have formed by subaerial erosion related to a sea-level fall combined with minor tilting of fault blocks and erosion of uplifted block crests.

In Late Jurassic time, the sand-rich depositional systems of the Pelion and Payer Dal Formations drowned and offshore transition - lower shoreface heteroliths and offshore mudstones of the Bernbjerg Formation accumulated. The fault block crest forming the eastern basin margin was inundated by a rise in relative sea level. Major fault activity probably occurred in latest Jurassic - Early Cretaceous times when the major fault block originally defining the Hold with Hope basin was split into smaller blocks.
\end{abstract}

Keywords: Hall Bredning Group, Hold with Hope, lithostratigraphy, North-East Greenland, palaeogeography, sedimentology, shallow marine, Spath Plateau Member, Vardekløft Group

H.V.*, M.L., S.P. \& J.T. ${ }^{\ddagger}$, Geological Survey of Denmark and Greenland, Øster Voldgade 10, DK-1350 Copenhagen K, Denmark. E-mail: mil@geus.dk

Present addresses: *Roskilde Amt, Køgevej 80, DK-4000 Roskilde, Denmark.

¥Skude E Jacobsen, Naestvedvej 1, DK-4760 Vordingborg, Denmark. 


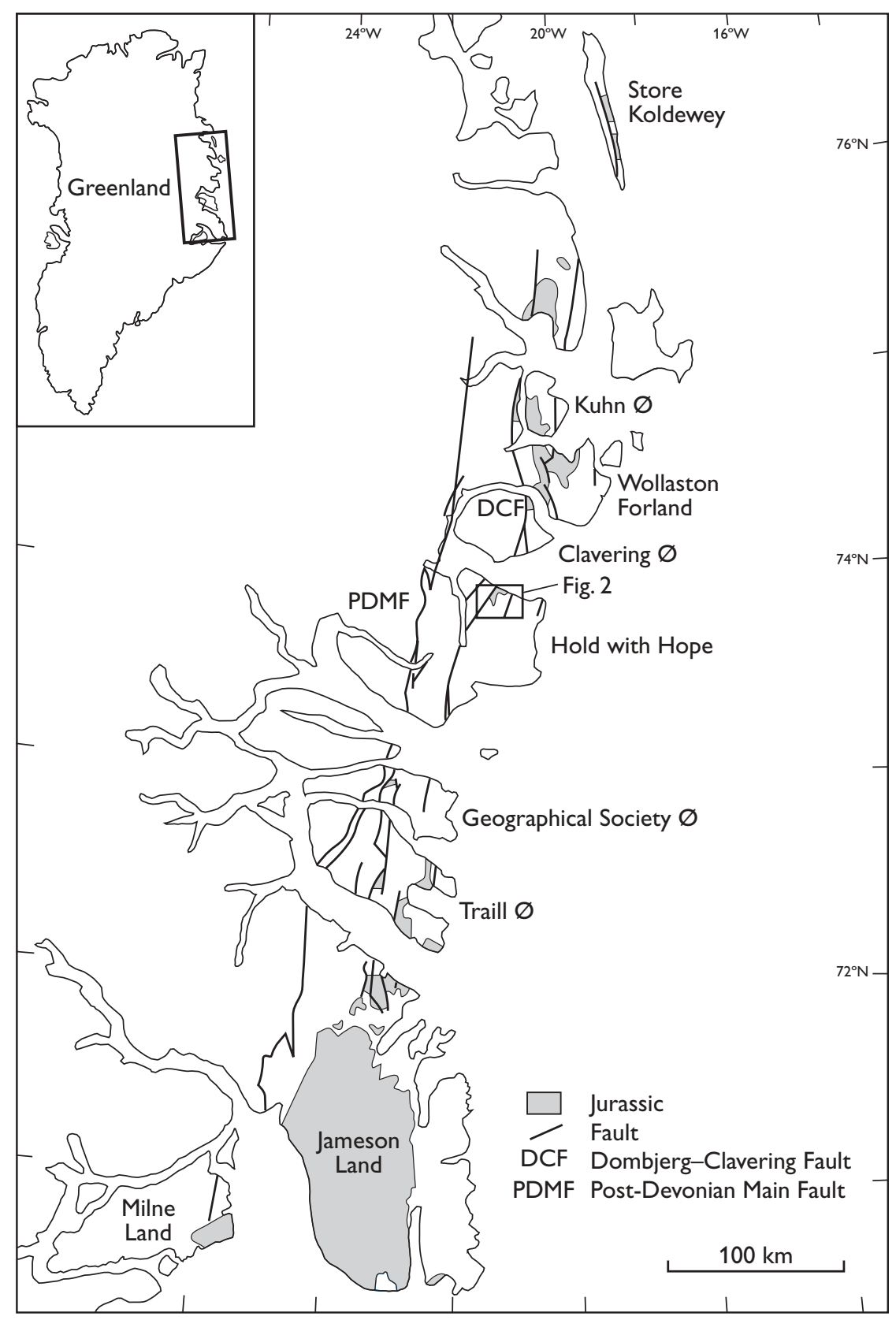

Fig. 1. Map of East Greenland showing the distribution of Jurassic sediments and major faults. Rectangle marks the investigated area on northern Hold with Hope, shown in more detail in Figure 2. Modified from Koch \& Haller (1971) and Surlyk et al. (1973).

A new Middle-Upper Jurassic succession, up to $360 \mathrm{~m}$ thick, was found recently on northern Hold with Hope, North-East Greenland (Fig. 1; Stemmerik et al. 1997; Kelly et al. 1998; Larsen et al. 1998). It spans the Early Callovian - Early Kimmeridgian time interval as indicated by dinoflagellate cysts and ammonites, and consists of coarse-grained sandstones overlain by heteroliths and mudstones. The sandstone-dominated lower part of the succession assigned here to the Pelion Formation was originally studied by Koch (1932) and Maync (1949) and was tentatively given an Early Cre- taceous age, although W. Maync noted the resemblance to the Middle Jurassic succession on Wollaston Forland.

The apparent absence of Jurassic sediments in the Hold with Hope area was explained differently by Maync (1947), Donovan (1957), Surlyk (1977) and Stemmerik et al. (1993). Maync (1947) and Surlyk (1977) suggested that during the Jurassic the area formed a landmass between the Wollaston Forland Basin to the north and the Jameson Land Basin to the south, implying that the lack of sediments was primarily due to non-deposition. Donovan (1957) in contrary found it 


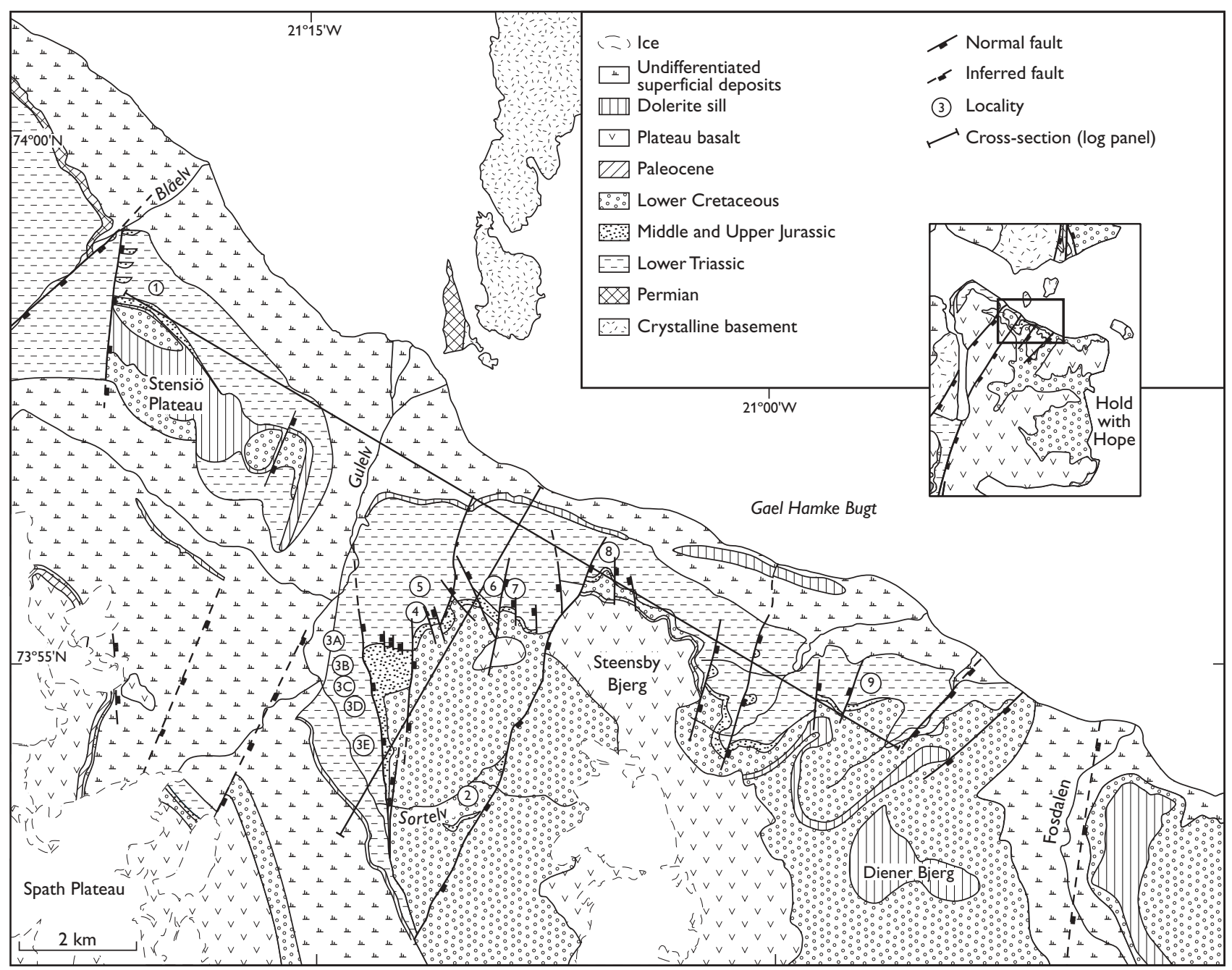

Fig. 2. Geological map of part of northern Hold with Hope including position of localities mentioned in text. The composite section from Gulelv (Fig. 5) was compiled from five part-sections (A-E). The solid lines show schematically the orientation of the NE-SW and NW-SE log panels in Figures 7 and 8, respectively.

most likely that the absence was secondary owing to pre-Aptian erosion of the Jurassic rocks. Based on comparison with nearby Clavering $\varnothing$, Stemmerik et al. (1993) suggested that Middle-Upper Jurassic sediments were present in the subsurface east of the continuation of the Dombjerg-Clavering Fault on Hold with Hope (Fig. 1, DCF).

The present investigations confirm that Hold with Hope formed a landmass between the Wollaston Forland and Jameson Land Basins during much of the Middle Jurassic time interval. The discovery on Hold with Hope of a marine succession of Early Callovian Kimmeridgian age, however, shows that the land mass was flooded in late Middle Jurassic time and continued to be sea-covered for most of the remaining Jurassic period.
The Jurassic succession on Hold with Hope is subdivided into shallow marine sandstones of the Pelion and Payer Dal Formations (Vardekløft Group) and lower shoreface - offshore transition heteroliths and offshore mudstones of the Bernbjerg Formation (Hall Bredning Group). The Pelion Formation includes the new Spath Plateau Member, which contains abundant sandy heteroliths in contrast to the dominant clean sandstone lithology of the Pelion Formation. The sedimentary facies of the units are described and the depositional environments interpreted. The Jurassic succession is placed within a regional framework including the Wollaston Forland and Jameson Land Basins to the north and south, respectively. 


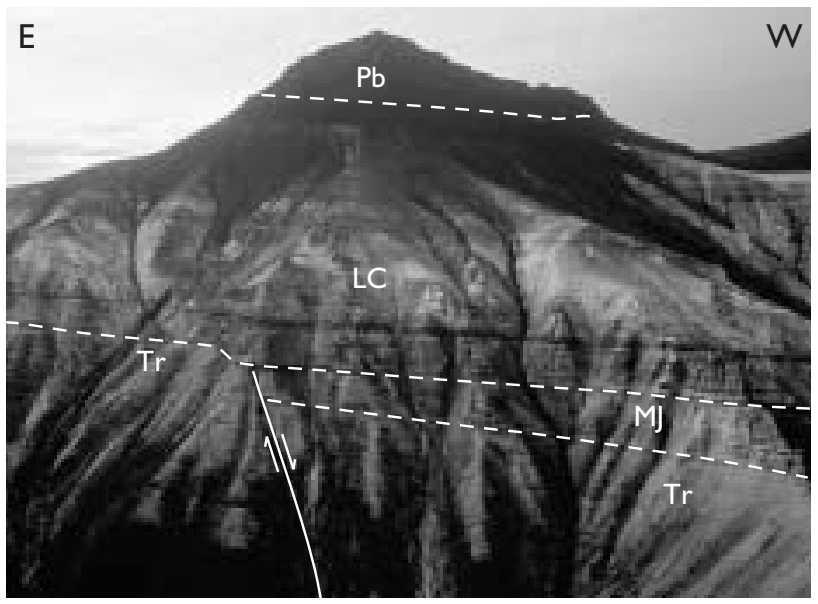

Fig. 3. Triassic-Paleocene succession exposed at Steensby Bjerg, northern Hold with Hope, viewed towards the south. The Triassic (Tr) and Middle Jurassic (MJ) sediments dip towards the southwest and are unconformably overlain by Lower Cretaceous (LC) sediments. A post-Kimmeridgian - pre-Barremian normal fault striking north-south offsets the Triassic and Jurassic sediments by at least $30 \mathrm{~m}$. View towards the south. From Larsen et al. (1998). The exposure shown is c. $200 \mathrm{~m}$ high and capped by Paleocene basalts $(\mathbf{P b})$.

\section{Geological setting}

The Late Palaeozoic - Mesozoic extensional basin complex in East Greenland is about $700 \mathrm{~km}$ long in a northsouth direction. This complex is situated over structurally controlled en echelon troughs and forms a wedgeshaped embayment with the narrowest onshore part to the north. Jurassic sediments are present in the Wollaston Forland and Jameson Land Basins situated on the western margin of the rift complex. In both basins, sediment transport in Middle Jurassic time was mainly longitudinal from north to south along a low gradient basin floor, which was not differentiated into a shelf, slope and deep-water basin (Surlyk 1977, 1990, 1991; Surlyk et al. 1981; Surlyk \& Clemmensen 1983).

In the Wollaston Forland Basin, rifting was initiated in Middle Jurassic time, and marine Bajocian-Bathonian sandstones onlap weathered Caledonian basement rocks or Upper Permian carbonates. Deposition took place on the hangingwall of wide W-SW-tilted fault blocks. Jurassic rifting culminated in the Volgian with strong rotational block faulting associated with conglomeratic submarine fan sedimentation (Surlyk 1978). During this tectonic episode, the wide fault blocks originally defining the Wollaston Forland Basin were split into smaller blocks (Vischer 1943; Surlyk 1978).

The Jurassic sediments on Hold with Hope occur on the hangingwall of small fault blocks that dip mainly towards the west and south-west (Fig. 2). Bedding planes within the Triassic and Jurassic successions seem to be parallel whereas the boundary to the overlying Cretaceous succession is an angular unconformity (Fig. 3).

The Jurassic succession shows marked lateral thickness variations depending on its position on the hangingwall. The thickness increases down-dip whereas it is missing up-dip due to Early Cretaceous erosion on some of the block crests. Faults locally cut the Triassic and Jurassic successions, but not the overlying Cretaceous succession showing that fault activity took place in post-Kimmeridgian, but pre-Barremian time (Fig. 3). Most faults in the area, however, were reactivated during Cretaceous and Cenozoic times.

\section{Stratigraphy and sedimentology}

The Jurassic succession on Hold with Hope is subdivided into lithostratigraphic units known from Wollaston Forland and Kuhn $\varnothing$ (Fig. 4). Stratigraphic ages of the Jurassic succession are based on ammonites and dinoflagellate cysts (Piasecki et al. 2004, this volume). The oldest Jurassic ammonite found on northern Hold with Hope is Cranocephalites sp. indicating the Upper Bajocian C. pompeckji Chronozone (J.H. Callomon and P. Alsen, personal communications 1997). The ammonite was, however, not found in situ but in the basal Cretaceous conglomerate at Locality 4 and c. 150 m east of Locality 8 (Fig. 2).

The Jurassic outcrops occur between Stensiö Plateau in the west and Diener Bjerg in the east (Fig. 2). Towards the south, the Jurassic sediments are exposed along the eastern side of the Gulelv river and on the southern side of the Sortelv river. A composite section, $360 \mathrm{~m}$ thick, was measured in a north-south direction along Gulelv on the hangingwall of a fault block dipping $c .15^{\circ}$ towards the SSW and comprises segments 3A-E (Figs 5, 6). Lateral facies variations are illustrated by cross-sections oriented parallel (NE-SW) and perpendicular (NW-SE) to the overall palaeocurrent direction (Figs 2, 7, 8).

\section{Pelion Formation}

The Pelion Formation in the Jameson Land and Wollaston Forland Basins consists of shallow marine, medium- to coarse-grained sandstones of Late Bajocian Late Callovian age (Engkilde \& Surlyk 2003). On Hold 


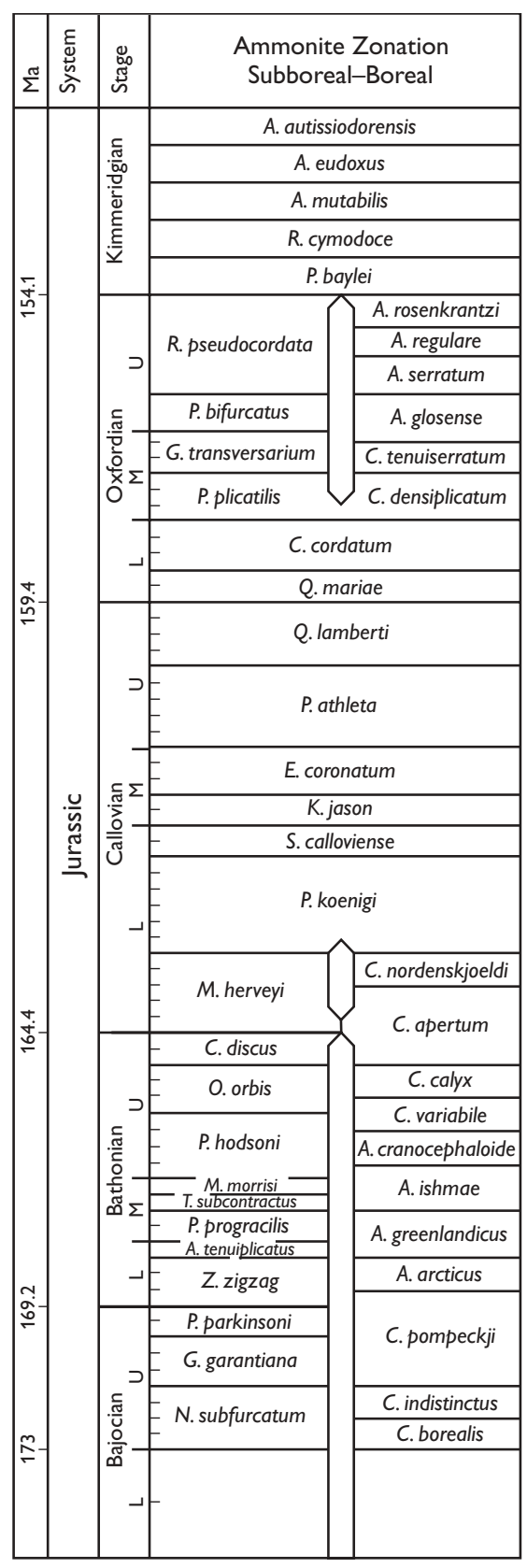

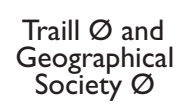

W

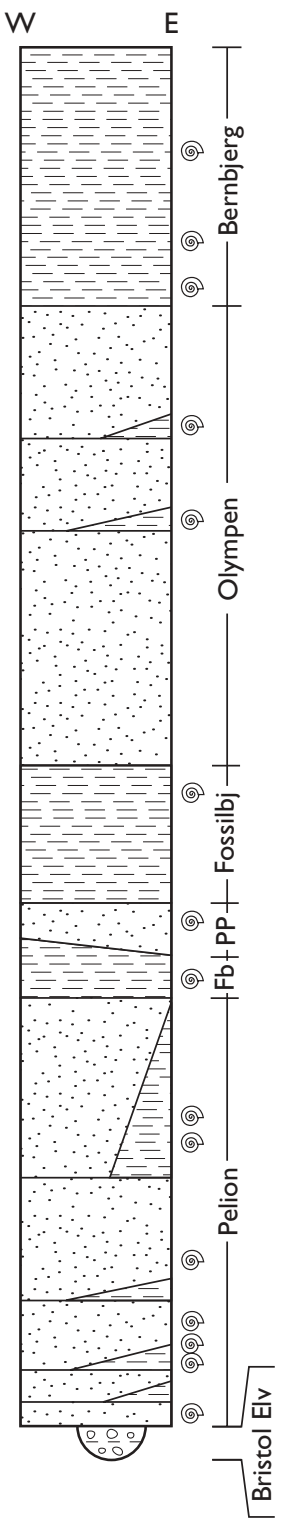

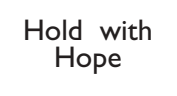
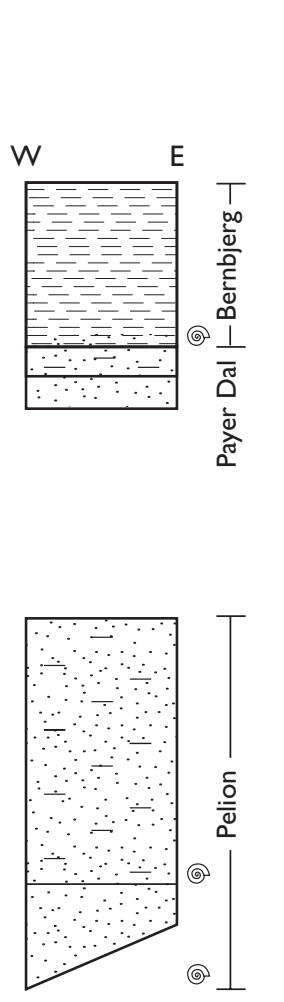

Wollaston Forland and Kuhn $\varnothing$

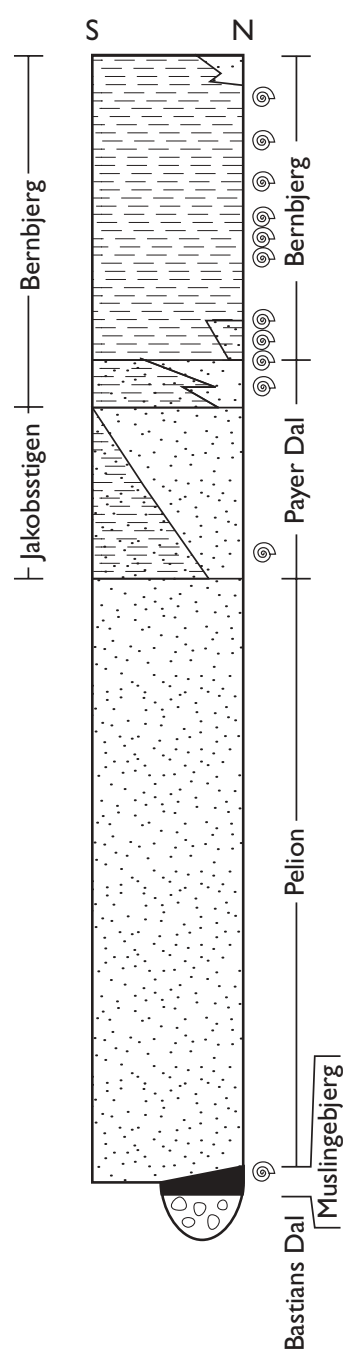

Legend

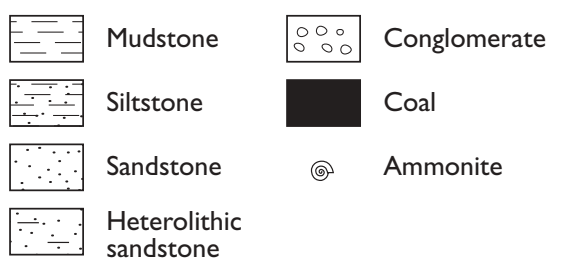

Fig. 4. Jurassic litho- and biostratigraphy (Lower Jurassic and Volgian not included) of the Traill $\varnothing-$ Geographical Society $\varnothing$ region, Hold with Hope and Wollaston Forland. Based on Surlyk (1977, 1978, 1990, 1991), Price \& Whitham (1997), Alsgaard et al. (2003), Alsen \& Surlyk (2004, this volume), Vosgerau et al. (2004, this volume) and own observations in the Traill $\varnothing$ and northern Hold with Hope areas. Fossilbj/Fb, Fossilbjerget; PP, Pelion (Parnas Mb). 


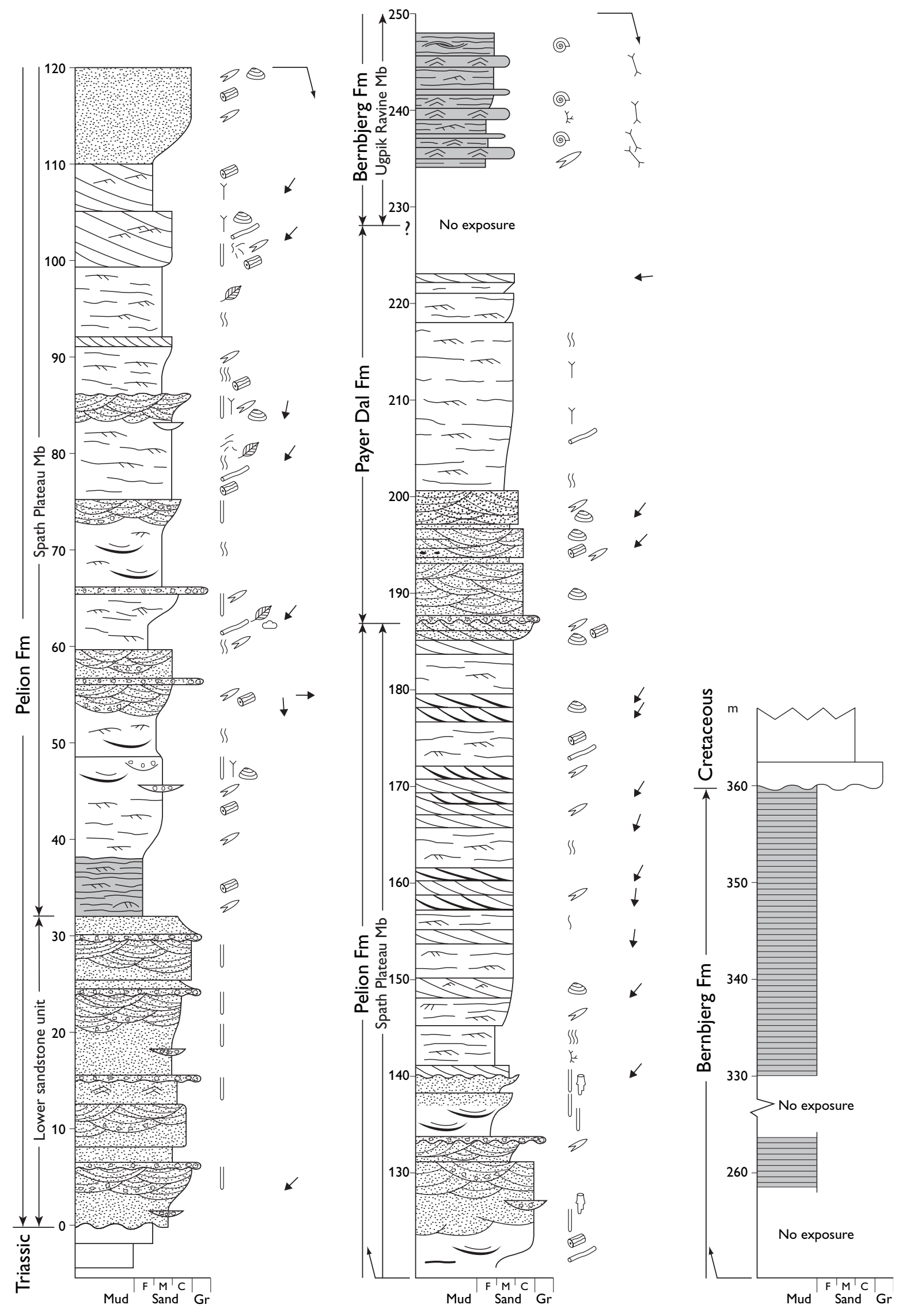


Sedimentary structures

Structureless

Facies associations

Upper shoreface

Lower-middle shoreface

Offshore - lower shoreface

Offshore
Fig. 5. Composite sedimentary section of the Middle-Upper Jurassic succession at Gulelv (Locality 3). The section was compiled from five part-sections located in a north-south direction along Gulelv (Figs 2, 6). Modified from Larsen et al. (1998).

\author{
Trace fossils \\ Bioturbation weak \\ I) Bioturbation moderate

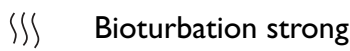 \\ U Diplocraterion \\ Y Monocraterion \\ \{ Ophiomorpha \\ 2 Planolites \\ $\infty$ Curvolithos

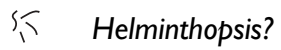 \\ Ke Chondrites
}

with Hope, a Lower-Middle Callovian sandy succession, c. $190 \mathrm{~m}$ thick, overlying the Lower Triassic Wordie Creek Formation is referred to the Pelion Formation (Fig. 5). The succession is divided into two units. The lower unit is $30-40 \mathrm{~m}$ thick and consists of medium- to coarse-grained sandstones topped by silty, fine-grained sandstones. The upper unit is up to $155 \mathrm{~m}$ thick and differs from the clean sandstones that typify the for- mation by containing abundant sandy heteroliths interbedded with cross-bedded sandstones and is included in the Spath Plateau Member (Fig. 5). The lower sandstone unit and the Spath Plateau Member are described and interpreted separately below; the latter member is defined formally as a new member of the Pelion Formation. 


\section{Lower sandstone unit}

The lower sandstone unit overlies siltstones and finegrained sandstones of the Lower Triassic Wordie Creek Formation with a sharp erosional boundary. The upper boundary is placed where coarse-grained sandstones are overlain by silty, very fine-grained sandstones of the Spath Plateau Member (Figs 5, 9).

The ammonite Cadoceras cf. breve indicating the Lower Callovian C. apertum Chronozone (J.H. Callomon and P. Alsen, personal communications 1997) was found $10 \mathrm{~m}$ above the Triassic-Jurassic boundary at Stensiö Plateau (Fig. 2, Locality 1). The basal part of the unit seems to be younger east of Stensiö Plateau (Fig. 2, Localities 4-9) where dinoflagellate cysts indicate the Lower Callovian P. koenigi Chronozone. The age of the upper boundary is constrained by an ammonite and by dinoflagellate cysts found in the basal part of the overlying Spath Plateau Member indicating the Lower Callovian P. koenigi Chronozone (see below).

The lower sandstone unit consists of pebbly, medium- to coarse-grained quartz sandstones, which are trough cross-bedded with sets up to $0.5 \mathrm{~m}$ thick or locally appear structureless. Small scour-fills with pebbles, up to $3 \mathrm{~cm}$ in diameter, are common. Dip-directions of foresets show a dominance towards the SW, but directions towards the NW also occur (Fig. 10). The sandstones commonly form coarsening-upwards units, 6-8 $\mathrm{m}$ thick, which locally are overlain by an erosionally based pebbly sandstone lag. The top part of the coarsening-upwards units is commonly calcite cemented and contains abundant vertical trace fossils of Diplocraterion habichi. Other trace fossils include Monocraterion tentaculatum and locally Ophiomorpha nodosa. Belemnites, bivalves and silicified wood are common. The unit is slightly finer grained in places and medium-grained sandstones occur at Locality 1 , Stensiö Plateau (Fig. 8). They contain low-relief scour surfaces draped by organic-rich mudstone and are strongly bioturbated with both horizontal and vertical burrows. The lower sandstone unit increases in thickness from $c .30$ to $40 \mathrm{~m}$ from the SW towards the NE (Fig. 7).

Deposition took place in a marine environment as reflected by marine macrofossils and trace fossils. The coarse-grained and pebbly sandstones and the dominance of vertical burrows suggest shallow-water deposition under high-energy conditions. The scour-fills are interpreted to have been formed by strong currents related to storm surges (e.g. Clifton et al. 1971; Hunter et al. 1979). The trough cross-bedded sandstones probably reflect 3-D dunes migrating seawards to the southwest in rip channels and partly longshore in runnels towards the north-west. Erosionally-based pebbly sandstones with marine macrofossils form the uppermost beds of some of the coarsening-upwards units and are interpreted as marine lag deposits, formed by wave winnowing of underlying upper shoreface and foreshore deposits. The coarsening-upwards units are interpreted to have formed mainly by shallow marine shoreface progradation. The probable source of the calcite cement in the top part of the coarsening-up-

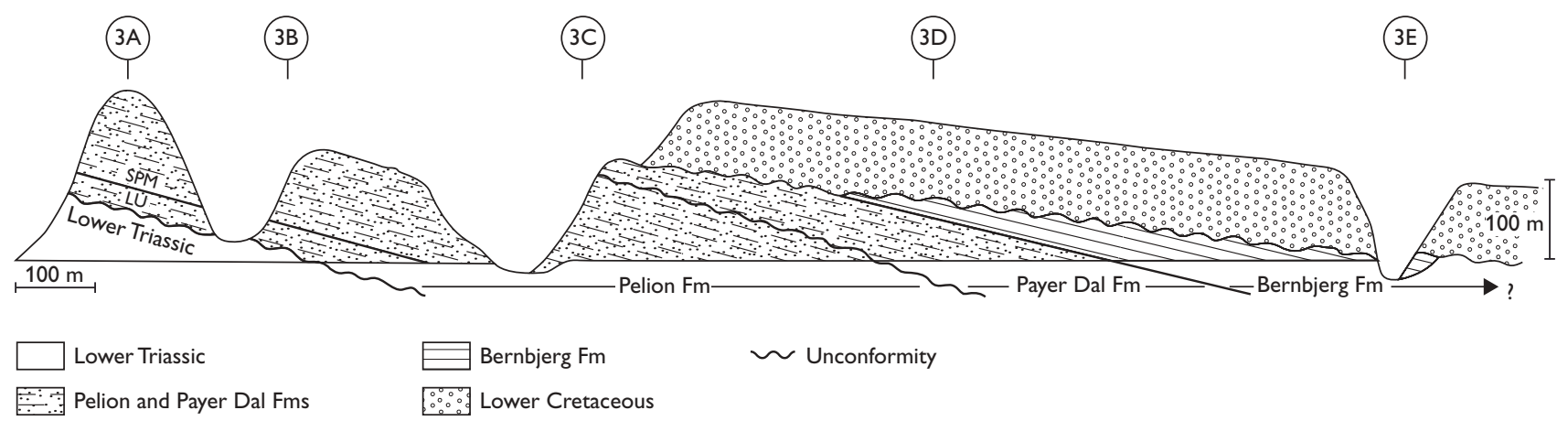

Fig. 6. Sketch of Triassic-Cretaceous succession exposed in a fault block on the eastern side of the Gulelv river (Fig. 2). The location of the part-sections that make up the composite section in Figure 5 are shown. The Triassic and Jurassic sediments dip $c$. $15^{\circ}$ towards SSW and are unconformably overlain by Cretaceous sediments, which dip $c .10^{\circ}$ towards the south. An angular unconformity between the Pelion and Payer Dal Formations is observed on the north-facing valleyside at 3C (see Fig. 11). LU, Lower sandstone unit; SPM, Spath Plateau Member. 
wards units is biogenic carbonate derived from calcareous shells accumulated on the marine omission surfaces (Alsgaard et al. 2003; Engkilde \& Surlyk 2003).

The strong bioturbation and the thin mudstone layers in the medium-grained sandstones at Stensiö Plateau suggest deposition under lower energy conditions. The mudstone drapes on the scour-surfaces formed by suspension fall-out during fair-weather conditions following erosional storm events. The sandstones were probably deposited in a slightly deeper, middle shoreface environment, than the medium- to coarse-grained sandstones that dominate the lower sandstone unit east of Stensiö Plateau.

The decrease in thickness of the sandstone unit from NE to SW combined with the dominant south-westwards palaeocurrent directions may reflect a NE-SW proximal-distal trend. In the proximal areas, a large sediment supply may have delayed the overall drowning recorded by the boundary to the overlying Spath Plateau Member. The increase in thickness towards the NE may, however, also reflect the relief of the palaeoshoreface.

\section{Spath Plateau Member}

new member

General. The member comprises mainly cross-bedded sandstones and sandy heteroliths forming the upper part of the Pelion Formation on northern Hold with Hope.

Name. After the ice-covered basalt plateau south-west of Gulelv, northern Hold with Hope.

Type locality. East side of Gulelv (Figs 2, 6, Locality 3) where the composite type section (Fig. 5) is defined from sub-sections A-C.

Thickness. $155 \mathrm{~m}$.

Lithology. The Spath Plateau Member consists of quartzitic sandstones and sandy heteroliths. A silty, very fine-grained sandstone bed occurs in the basal part of the member. Belemnites, bivalves, silicified and coalified wood and impressions of leaf fragments are common.

Boundaries. The lower boundary is marked by an abrupt change from coarse-grained sandstone of the lower sandstone unit of the Pelion Formation to silty, fine-grained sandstone. The upper boundary is sharp and erosional and is overlain by pebbly sandstone and sandy heteroliths of the Payer Dal Formation.

Distribution. The member occurs on northern Hold with Hope.

Age. Early-Late Callovian based on an ammonite found at the base of the member and dinoflagellate cysts (Fig. 7, Locality 6). The ammonite is a microconch and resembles Cadoceras septentrionale indicating the lowermost part of the Lower Callovian P. koenigi Chronozone (P. Alsen, personal communication 1998). Dinoflagellate cysts from the base of the member also indicate the C. apertum - P. koenigi Chronozones (Piasecki et al. 2004, this volume). Dinoflagellate cysts in the upper part of the member indicate the Upper Callovian P. athleta Chronozone (Piasecki et al. 2004, this volume).

Facies description. The basal part of the member consists of dark brown, silty sandstones forming a $6 \mathrm{~m}$ thick marker bed, situated 30-40 $\mathrm{m}$ above the base of the Jurassic succession (Figs 5, 7, 9). The basal $0.5 \mathrm{~m}$ of the bed locally contain scattered fine pebbles up to $6 \mathrm{~mm}$ in diameter, but otherwise the unit coarsens upwards from silty, very fine-grained sandstone into silty fine-grained sandstone. The sandstones are horizontally laminated, structureless or show subtle wave or current cross-lamination with thin organic-rich mudstone drapes, but primary structures are to a large extent obscured due to weathering or strong bioturbation. In a few places, laminae of silty sandstone are deflected around small, elongate carbonate-cemented concretions. Coalified wood fragments up to $30 \mathrm{~cm}$ long and belemnites are abundant in the basal part of the bed, and a few bivalves and gastropods were found immediately above the lower boundary at Locality 6 (Fig. 7) together with the ammonite Cadoceras septentrionale. The organic content (TOC) is low, about $1 \mathrm{wt} \%$.

The fine-grained marker bed forms the base of the Spath Plateau Member and sharply overlies trough cross-bedded sandstones or conglomerates of the lower sandstone unit of the Pelion Formation. However, at Locality 9 (Fig. 8), the basal unit of the member consists of a ripple cross-laminated sandy heterolith unit, c. $0.4 \mathrm{~m}$ thick, followed by medium- to coarse-grained, planar cross-bedded sandstones. The upper boundary to the overlying ripple cross-laminated sandy heteroliths is gradational. 
(Distal)

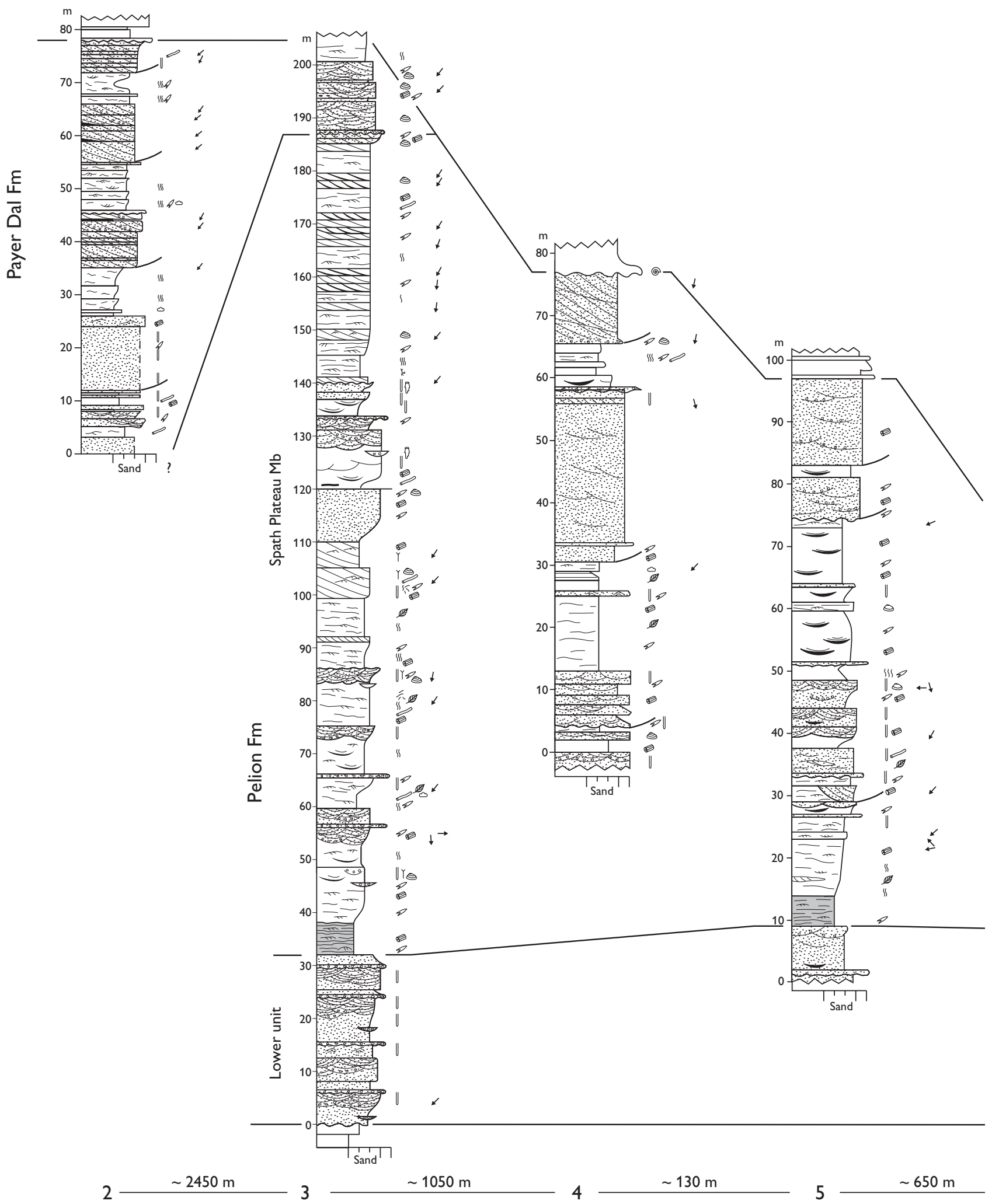


Fig. 7. Log panel giving a broadly NE (proximal) to SW

(distal) cross-section. For legend, see Fig. 5; for localities, see Fig. 2.

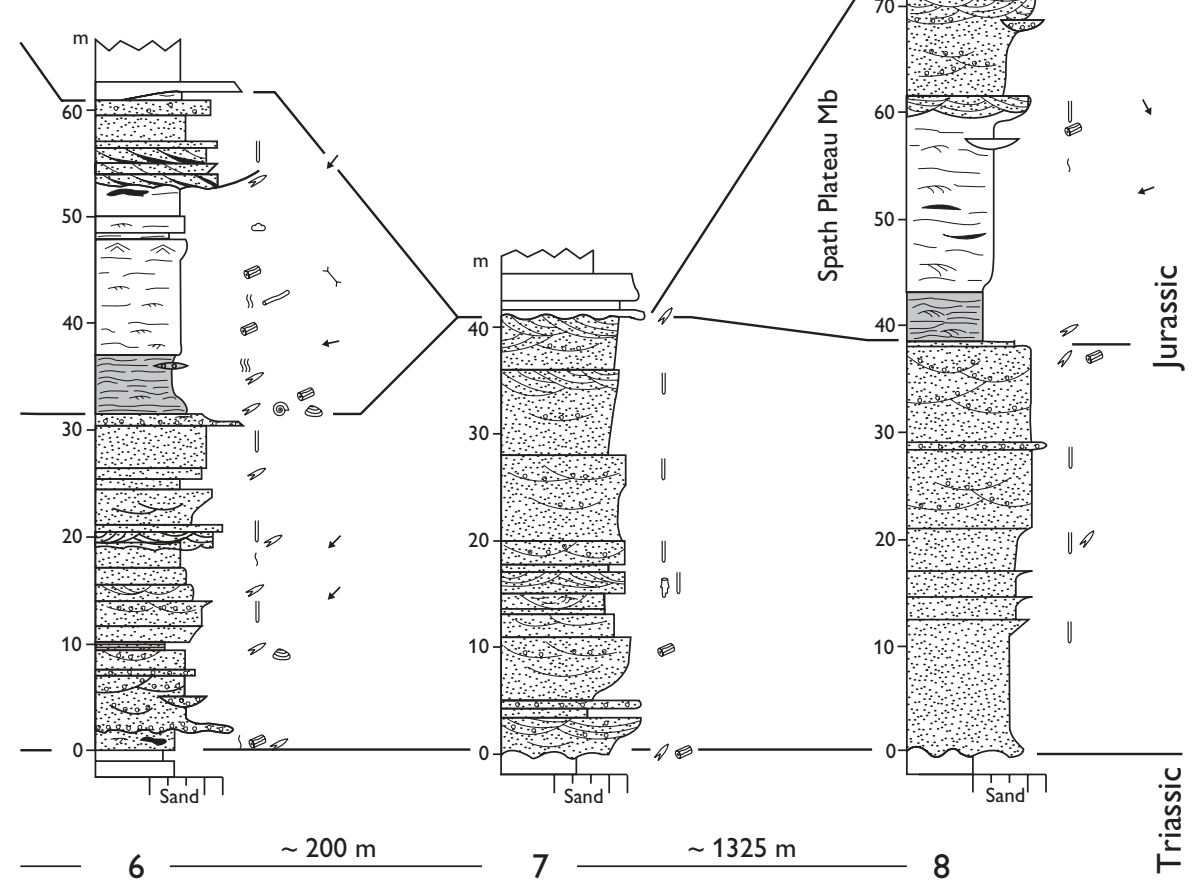




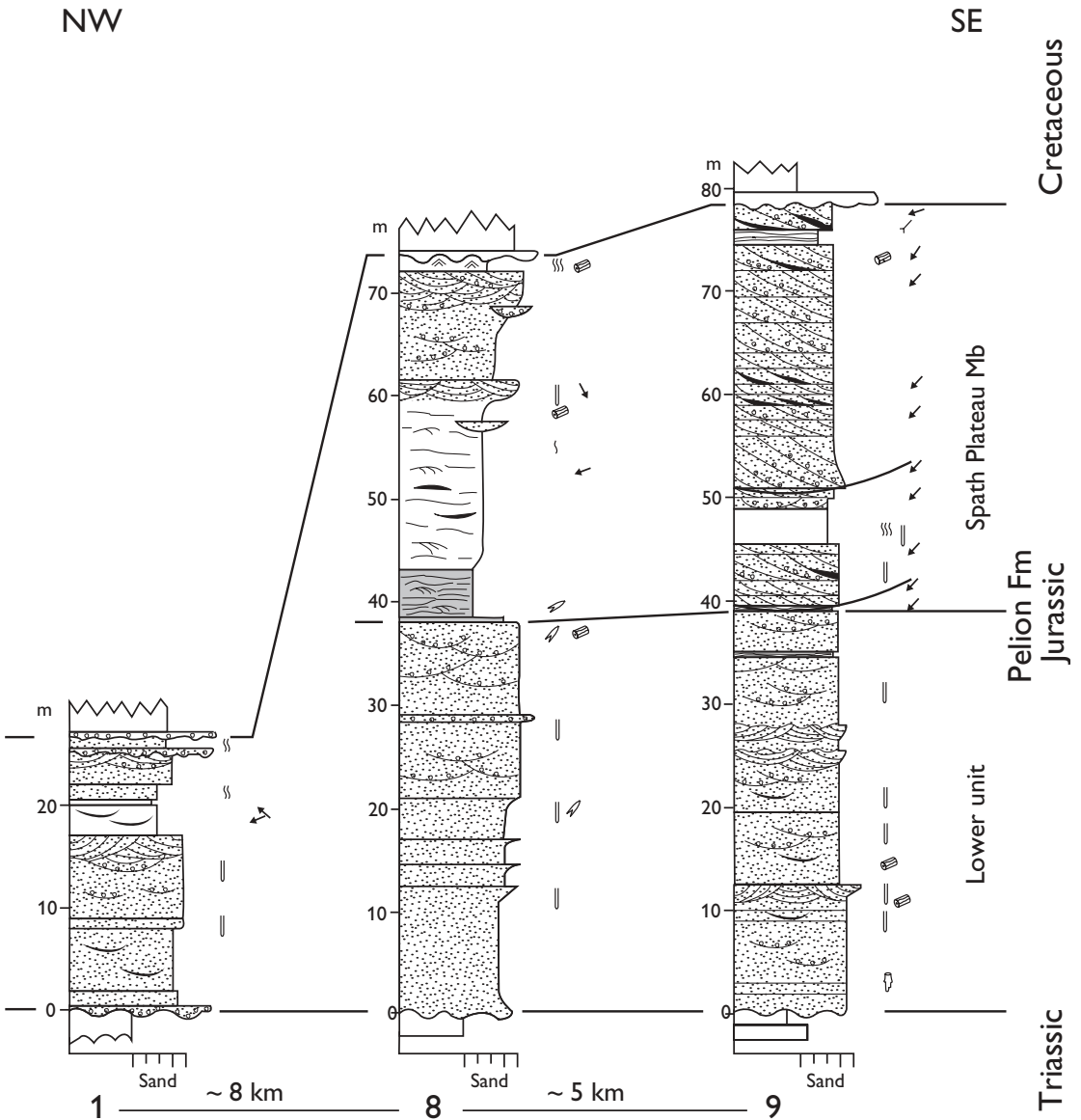

Fig. 8. Log panel giving a NW-SE strike section through the Jurassic succession. For legend, see Fig. 5; for localities, see Fig. 2.
The bulk of the member is made up of heteroliths forming units up to $10 \mathrm{~m}$ thick of cross-laminated, fineto medium-grained sandstones with thin organic-rich mudstone drapes. Both symmetrical and asymmetrical ripples, $1-5 \mathrm{~cm}$ high and with wavelengths up to 10 $\mathrm{cm}$, occur. The heteroliths locally form cross-strata, up to $1.5 \mathrm{~m}$ thick, with very low-angle foresets and set boundaries marked by indistinct toesets of dark, sandy mudstones, a few centimetres thick. Scour surfaces with a relief of up to $20 \mathrm{~cm}$ are common in the heteroliths. Locally, structureless sandstones overlie the surfaces. The degree of bioturbation varies from moderate to high (up to 100\%) and the trace fossil assemblage includes Planolites beverleyensis, Curvolithos multiplex, Monocraterion tentaculatum, Diplocraterion habichi and possibly Helminthopsis magna. Silicified and coalified wood fragments up to $1 \mathrm{~m}$ long, together with impressions of leaf fragments, are abundant and belemnites occur locally.

Two types of cross-bedded sandstones occur closely associated with the heteroliths in the Spath Plateau Member. They both show foresets mainly dipping towards the south-west (Fig. 10). The first type consists of planar or trough cross-bedded, fine- to coarsegrained sandstones occasionally with pebbles. Foresets are generally tangential and commonly separated by single and in places double, organic-rich mudstone drapes. Backflow ripples and reactivation surfaces occur locally. The sets are $0.5-5 \mathrm{~m}$ thick and form cosets up to $25 \mathrm{~m}$ thick. Set-boundaries are defined by organic-rich silty sandstone beds $1-10 \mathrm{~cm}$ thick, representing distal toesets. In one place, however, the toesets form a lenticular body of organic-rich shale, $40 \mathrm{~m}$ long and $0.5 \mathrm{~m}$ thick, with gently inclined laminae (to SW). The cross-bedded, coarse-grained sandstones commonly overlie ripple cross-laminated sandy heteroliths with a sharp erosional boundary, and contain belemnites, bivalve shells and coalified wood. The degree of bioturbation is low and the trace fossils include vertical burrows of Monocraterion tentaculatum, Diplocraterion habichi and Arenicolites isp. The first type of cross-bedded sandstones form a c. $40 \mathrm{~m}$ thick succession in the lower part of the Spath Plateau Member at Locality 9, Diener Bjerg, whereas heteroliths are abundant in the lower part at the other localities (Figs 7, 8).

The second type of cross-bedded sandstones is fine- 


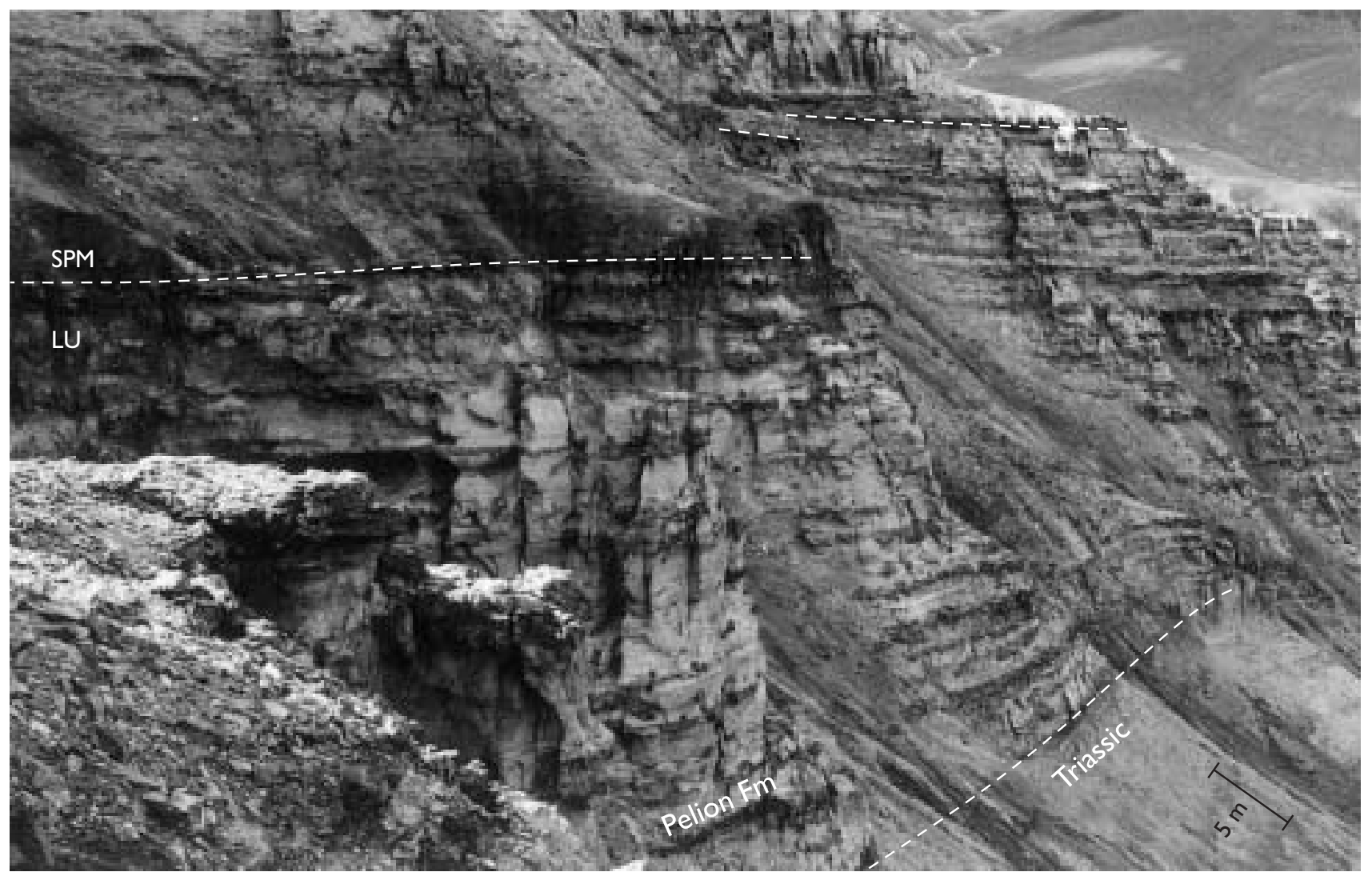

Fig. 9. Triassic siltstones and sandstones overlain by concretionary sandstones of the lower sandstone unit (LU) of the Pelion Formation. A marine drowning surface (dashed line) separates the lower sandstone unit from an overlying dark brown silty sandstone bed which form the basal part of the Spath Plateau Member (SPM), Pelion Formation. Fig. 2, Locality 6.

to medium-grained and consists of up to $5 \mathrm{~m}$ thick sets of low-angle master beds separated by thinner crossbedded or ripple cross-laminated sets. The latter commonly show climbing ripple cross-lamination or locally bi-directional cross-laminae. The surfaces of the low-angle master beds may be wave or current rippled and separated by thin mudstone drapes. Set thickness is $1-5 \mathrm{~m}$. The lower boundary to ripple laminated sandy heteroliths is generally gradational. The sandstones contain belemnites, bivalve shells and coalified wood. The degree of bioturbation is moderate to high. Trace fossils include vertical burrows of Monocraterion tentaculatum, Diplocraterion habichi and Arenicolites isp., forms that are also common in the first type of sandstones, together with horizontal burrows of Planolites beverleyensis and possibly Helminthopsis magna in the intervening mud drapes.

Trough cross-bedded sandstones similar to those in the lower sandstone unit of the Pelion Formation occur locally in the Spath Plateau Member (Fig. 7). They commonly form coarsening-upwards successions, up to $5 \mathrm{~m}$ thick, the most complete of which have a lower part consisting of well-sorted, fine- to medium-grained sandstone with indistinct ripple cross-lamination, trough cross-bedding and shallow scour fills. The scour fills are $10-30 \mathrm{~cm}$ thick and are marked by thin, organicrich mudstone layers above the lower erosional boundaries followed by laminated or structureless sandstones. The upper part of the coarsening-upwards units consists of trough cross-bedded, medium- to coarse-grained sandstones. Foresets dip mainly towards the south, but dip-directions towards the west and east also occur (Fig. 10). The upper part is commonly calcite cemented and capped by a sharp surface from which abundant Diplocraterion habichi descend; other trace fossils in the upper levels include Monocraterion tentaculatum and occasional Ophiomorpha nodosa. Horizontal burrows of Planolites beverleyensis are limited to the lower part of the coarsening-upwards units. Belemnites, bivalves and silicified wood are common.

Facies interpretation. The laminated silty sandstone 
Pelion Fm

(lower sandstone unit)

$\mathrm{N}=11$

$\overline{\mathrm{V}}=243^{\circ}$

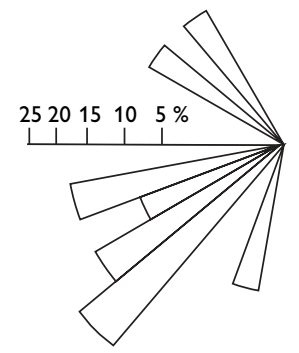

Trough cross-bedding
Pelion Fm

(Spath Plateau Member)

$\mathrm{N}=47$

$\bar{V}=220^{\circ}$
$\mathrm{N}=11$

$\bar{V}=175^{\circ}$

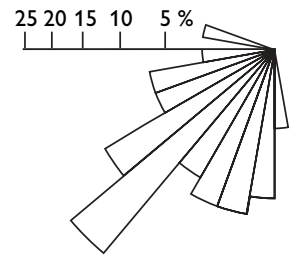

Trough and planar crossbedding, and low-angle master bedding
Payer Dal Fm

Bernbjerg Fm

\section{$\Gamma$}

\section{$\mathrm{N}=9$}

$\overline{\mathrm{V}}=221^{\circ}$

\section{$\mathrm{N}=8$}

$\bar{V}=231^{\circ}$

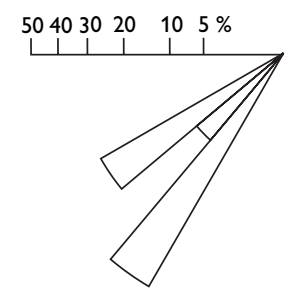

Trough and planar cross-bedding

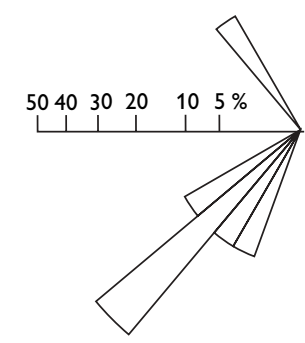

Trough cross-bedding
$N=14$
$\bar{V}=338^{\circ}$

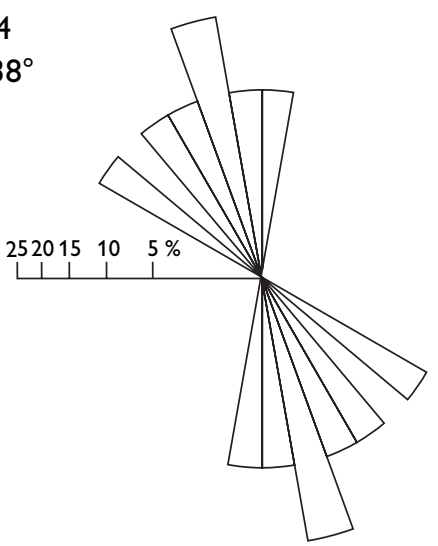

Wave ripple crest orientation

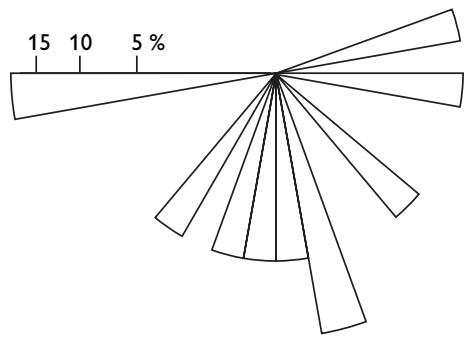

Trough cross-bedding

Fig. 10. Palaeocurrent and wave-ripple data from the Pelion, Payer Dal and Bernbjerg Formations. Rose diagrams are shown as true area plots. $\mathbf{V}$, vector mean; $\mathbf{N}$, number of measurements.

bed of the basal Spath Plateau Member (except at Locality 9), was deposited in a marine environment as reflected by the marine dinoflagellate cysts and abundant belemnites. The horizontal lamination was formed by deposition from suspension fall-out whereas the subtle cross-lamination was probably formed by waveinduced currents in the offshore transition to lower shoreface zone. The sharp boundary to the underlying upper shoreface sandstones of the lower sandstone unit represents a drowning surface. At Locality 9, Diener Bjerg, this surface is overlain by a sandy heterolith unit, c. $0.4 \mathrm{~m}$ thick, interpreted as having been deposited in the lower to middle shoreface zone. This lateral facies variation suggests that the palaeo-water depth decreased from west to east.

The alternation of ripple cross-laminated sandstones 
and mudstone drapes reflects varying energy conditions and may be related to the alternation of fairweather and storm-wave processes and perhaps tidal currents. The strongly bioturbated heteroliths reflect periods of slow sedimentation and little physical reworking whereas the scour surfaces and the overlying structureless sandstones which form part of the facies are interpreted as having formed by strong currents related to storm surges (Clifton et al. 1971; Hunter et al. 1979; Nemec \& Steel 1984). The abundant plant debris suggests a significant sediment supply from land.

The two types of cross-bedded sandstones are interpreted to represent SSW-migrating sandwaves. They were modified by waves and opposing tidal currents as seen by the presence of wave-ripples, mud drapes, reactivation surfaces and bimodal cross-lamination (Visser 1980; Boersma \& Terwindt 1981; Wood \& Hopkins 1989). The first type of cross-bedded sandstones was formed in shallow water, possibly the upper shoreface, as seen by the coarse grain-size and low degree of bioturbation. The sharp erosional lower boundaries to lower-middle shoreface heteroliths suggest that the migration of sandwaves took place in distributary channels. The marked lateral facies variation seen between Locality 9 and the other localities suggests that the thick cross-bedded succession at Locality 9 may represent a major distributary channel fill.

The second type of cross-bedded sandstones was formed in deeper water than the first type, as reflected by the generally finer grain-size, stronger bioturbation and the gradational boundary to underlying lowermiddle shoreface heteroliths. The compound cross-bedded sandstones with climbing ripple cross-laminated sets on the low-angle master bedding reflect suspension fall-out into deeper water and were possibly deposited in mouthbars (Elliott 1974; Gjelberg \& Steel 1995).

The trough cross-bedded sandstones are similar to those in the lower sandstone unit of the Pelion Formation and are similarly interpreted as having formed by migration of 3-D dunes in a high energy, shallow marine environment. The coarse grain size of the trough cross-beds from the upper part of the coarsening-upwards units suggests sediment supply from nearby distributary channels. The dominant southwards palaeocurrent direction indicates that land was situated towards the north, but the large variation in the palaeocurrent measurements and the limited dataset preclude detailed interpretation of the palaeo-shoreline orientation. The coarsening-upwards units are interpreted to reflect progradation in the middle to upper shoreface.

\section{Payer Dal Formation}

In the type area on Kuhn $\varnothing$, the Payer Dal Formation consists of fine- to coarse-grained quartz sandstones locally with pebbly sandstone lags rich in marine bivalves and belemnites (Alsgaard et al. 2003). The formation is subdivided into a lower and an upper unit that have an Early-Middle Oxfordian and early Late Oxfordian age, respectively (Fig. 4). On Hold with Hope, a succession of cross-bedded, medium- to coarse-grained quartz sandstones, pebbly sandstone lags and sandy heteroliths overlying the Pelion Formation is referred to the Payer Dal Formation.
Fig. 11. The Spath Plateau Member (Pelion Formation), Payer Dal Formation and overlying Cretaceous sandstones. Note the slight angular discordance at the unconformity between the Pelion and Payer Dal Formations (dashed line). Fig. 2, Locality 3C; view towards south.

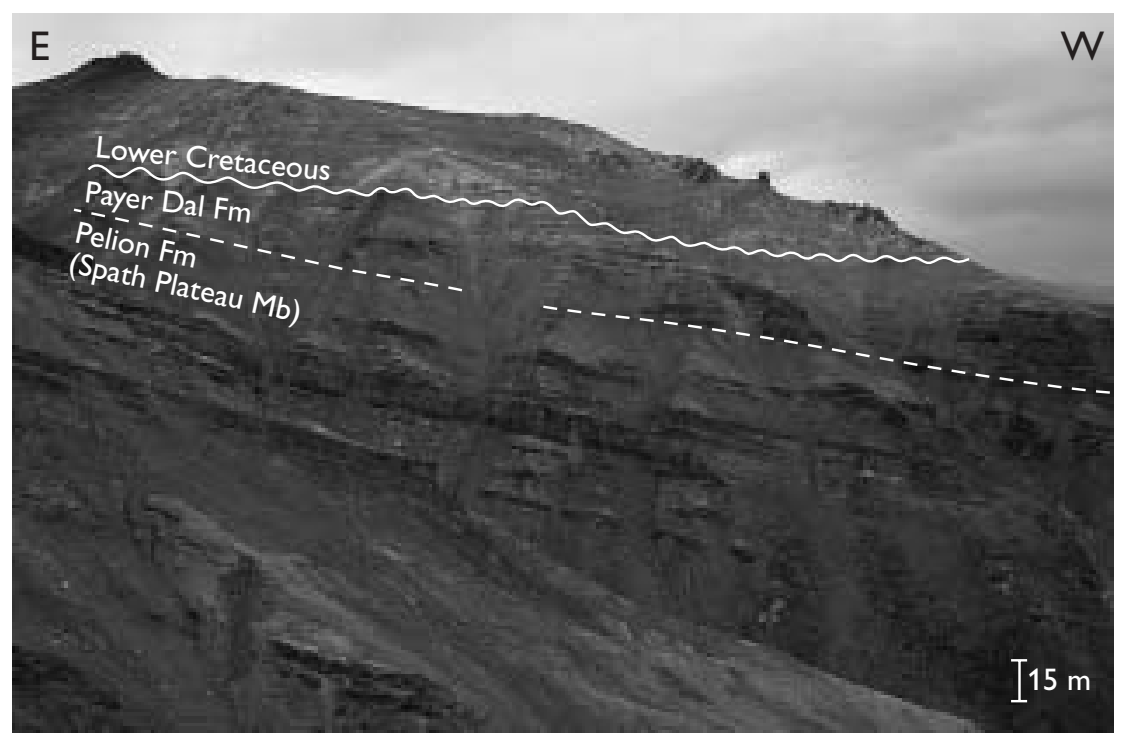




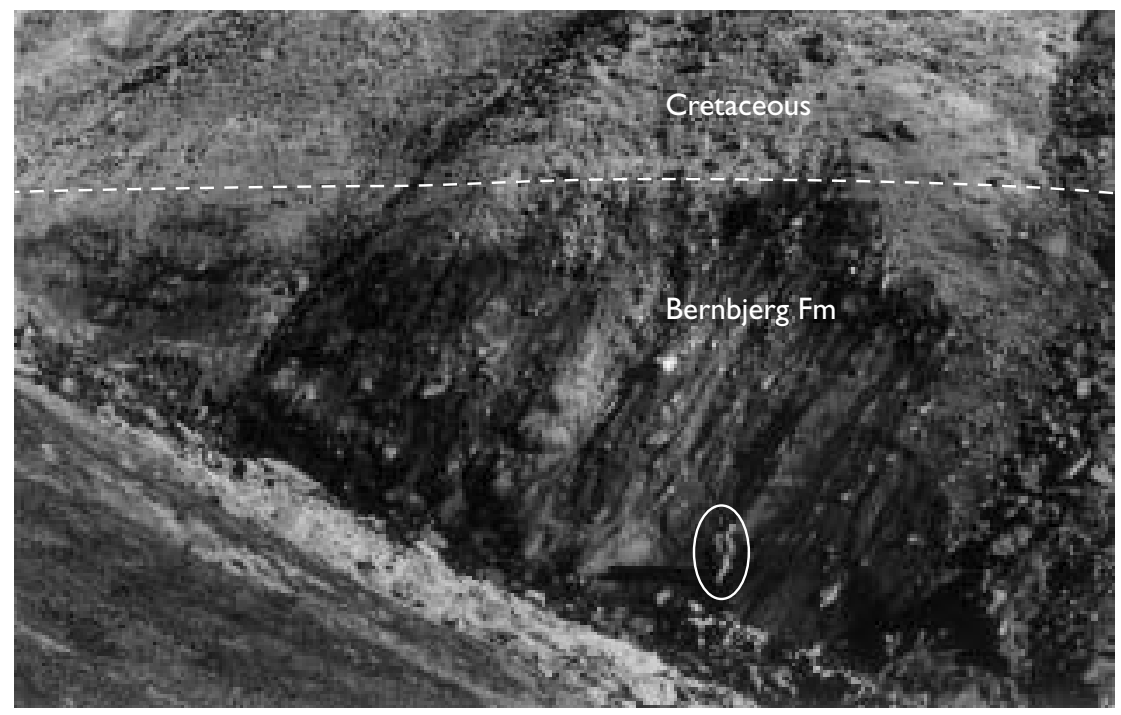

Fig. 12. Structureless and horizontally laminated dark mudstones of the Bernbjerg Formation erosionally overlain by Cretaceous sandstone (Fig. 6, Locality 3E; 340-360 $\mathrm{m}$ in Fig. 5). Person (encircled) for scale.

The age of the Payer Dal Formation on Hold with Hope is Middle-Late Oxfordian. Dinoflagellate cysts from the lower part of the Formation indicate the Middle-Upper Oxfordian C. tenuiserratum - A. glosense Chronozones, similar to the upper unit of the Payer Dal Formation on Kuhn $\varnothing$. This suggests that the boundary between the Pelion and Payer Dal Formations on Hold with Hope represents a Late Callovian Middle Oxfordian hiatus (Fig. 4).

The formation is exposed at Localities 2 and 3 (Figs $2,5,7)$. The lower boundary is only exposed at Locality 3 , where it is represented by an erosional surface forming a minor angular unconformity between the Pelion and Payer Dal Formations (Fig. 11). The surface is overlain by a pebbly sandstone lag, up to $0.5 \mathrm{~m}$ thick, of quartz pebbles $3-5 \mathrm{~mm}$ in diameter, belemnites, bivalves and small logs, up to $0.4 \mathrm{~m}$ long. The lag is overlain by a coarse- to very coarse-grained sandstone succession, c. $15 \mathrm{~m}$ thick, which fines slightly upwards. The succession is dominated by trough crossbedding but small sets of planar cross-beds and pebbly sandstone lags also occur. Dip directions of foresets are mainly towards the SW (Fig. 10). Pavements of bivalves are common, whereas belemnites, logs and rounded mudstone clasts, up to $5 \mathrm{~cm}$ in diameter, occur locally. The sandstone succession is capped by a sharp surface overlain by an overall coarsening-upwards unit (c. $25 \mathrm{~m}$ thick) of ripple cross-laminated sandy heteroliths, similar to those in the underlying Spath Plateau Member. At Locality 2, the formation is at least $70 \mathrm{~m}$ thick and consists of alternating ripple cross-laminated sandy heteroliths and sets of planar or trough cross-bedded, coarse-grained sandstones similar to the first type of cross-bedded sandstones of the Spath Plateau Member. The foresets dip towards the south-west (Fig. 10). The upper boundary to the Bernbjerg Formation is covered by scree, but is probably situated somewhere between $223 \mathrm{~m}$ and $234 \mathrm{~m}$ in the composite section at Locality 3 (Fig. 5).

The basal pebbly sandstone at Locality 3 is interpreted as a marine lag deposit due to the coarse grain size, the presence of marine macrofossils and the erosional base. The overlying cross-bedded sandstone succession was deposited in a high energy, shallow marine environment as testified by the coarse grain size, the pebbly sandstone lags and the marine macrofossils. The cross-bedded sandstones are interpreted to reflect the seawards migration of dunes in the upper shoreface. The coarse grain size of the sandstone succession and the occurrence of logs and rounded clay clasts suggest sediment supply from nearby distributary channels. The sandstone succession is topped by a drowning surface.

A slightly different depositional environment is recorded by the succession at Locality 2 where planar and trough cross-bedded distributary channel-fill sandstones alternate with lower-middle shoreface heteroliths. These facies are very similar to the facies of the underlying Spath Plateau Member and are similarly interpreted to reflect migration of dunes in distributary channels and mouth bars associated with tidally influenced deltas (see above).

The considerable thickness variation of the Payer Dal Formation between Localities 2 and 3, together 
with the presence of a minor angular unconformity at the base of the formation, might reflect differential subsidence due to the onset of fault-block tilting.

\section{Bernbjerg Formation}

The Upper Oxfordian - Lower Volgian Bernbjerg Formation in Wollaston Forland is dominated by darkgrey to black mudstones and strongly bioturbated heteroliths (Surlyk 1977; Surlyk \& Clemmensen 1983). On Hold with Hope, the formation is poorly exposed along the Gulelv river (Figs 2, 6) where it is estimated to be c. $130 \mathrm{~m}$ thick based mainly on simple geometrical calculations. It has not been possible to study lateral facies variations within the Bernbjerg Formation.

The basal part of the Bernbjerg Formation on Hold with Hope has a Late Oxfordian, A. glosense Chron age based on the presence of the ammonite Amoeboceras ilovaiskii (J.H. Callomon and P. Alsen, personal communications 1997) and dinoflagellate cysts (Piasecki et al. 2004, this volume). In the upper part of the formation, dinoflagellate cysts indicate a Late Oxfordian -Early Kimmeridgian, A. serratum - P. baylei Chron age (Piasecki et al. 2004, this volume).

The basal part of the Bernbjerg Formation on Hold with Hope is dominated by organic-rich, silty, finegrained sandstones, which are horizontally laminated or locally cross-laminated. Wave-rippled, medium- to coarse-grained sandstone beds, locally with pebbles up to $1 \mathrm{~cm}$ in diameter, are common. The wave ripples have NW-SE ripple crest orientations (Fig. 10; 234 $248 \mathrm{~m}$ in Fig. 5). The silty fine-grained sandstones contain scattered Chondrites isp. Belemnites occur locally whereas ammonites are abundant. This lower coarsergrained unit of the Bernbjerg Formation is referred to the Ugpik Ravine Member (Surlyk 2003, fig. 5).

The succession above the basal part of the Bernbjerg Formation consists of structureless or horizontally laminated dark mudstones (Fig. 12). No macrofossils were found in the mudstones. Total organic carbon (TOC) content is about $2 \mathrm{wt} \%$ based on two samples. The lower boundary of the Bernbjerg Formation is not exposed, and the formation is erosionally overlain by Lower Cretaceous coarse-grained sandstones. The Bernbjerg Formation probably continues into the subsurface along Gulelv.

The horizontally laminated and locally cross-laminated silty fine-grained sandstones from the basal part of the Bernbjerg Formation reflect deposition from suspension fall-out and weak bottom currents during fair-weather conditions. Storm-wave currents most likely deposited the interbedded wave-rippled, medium to coarse-grained sandstones. The orientations of the wave ripples suggest a NW-SE-trending coastline. The facies are interpreted to have been deposited in the offshore transition to lower shoreface zone. The overlying dark mudstones are interpreted to have been deposited offshore from suspension fall-out based on the fine grain size and dominant horizontal lamination.

\section{Palaeoenvironments and basin configuration}

The Jurassic succession on Hold with Hope shows a stepwise, but overall fining-upwards trend (Fig. 5) reflecting long-term transgression. The transgression was interrupted by a major relative sea-level fall within the Late Callovian - Middle Oxfordian time interval, represented by the unconformity separating the Pelion and Payer Dal Formations.

The basal Jurassic sediments seem to get younger from west to east as suggested by dinoflagellate cysts indicating the Lower Callovian C. apertum Chronozone at Stensiö Plateau and the Lower Callovian P. koenigi Chronozone at Steensby Bjerg and Diener Bjerg (Fig. 2). The age difference may reflect onset of rifting and associated onlap. Alternatively, the Stensiö Plateau formed a separate fault block, which was transgressed first. The N-S-trending fault situated at Blåelv, west of Stensiö Plateau, forms the western boundary of Jurassic sediments today (Fig. 2). The Jurassic sea, however, may have extended as far west as to the PostDevonian Main Fault, which formed the western basin boundary during the Late Permian and Triassic (Vischer 1943; Birkelund \& Perch-Nielsen 1976; Stemmerik et al. 1993). This would imply that older Jurassic sediments from the western part of the basin were eroded in post-Kimmeridgian time. Transport of eroded material towards the east may explain the occurrence of Cranocephalites sp., indicating the Upper Bajocian $C$. pompeckji Chronozone, in the Cretaceous basal conglomerate at Steensby Bjerg. The sediment source area may, however, also have been Clavering $\varnothing$, west of the Dombjerg-Clavering Fault, which is believed to have formed a palaeo-high in Jurassic times (Vischer 1943; Stemmerik et al. 1993).

Lateral facies variations within the Spath Plateau Member (Pelion Formation) indicate that palaeo-water depths decreased from west to east. This suggests a similar setting to that envisaged for the Wollaston For- 


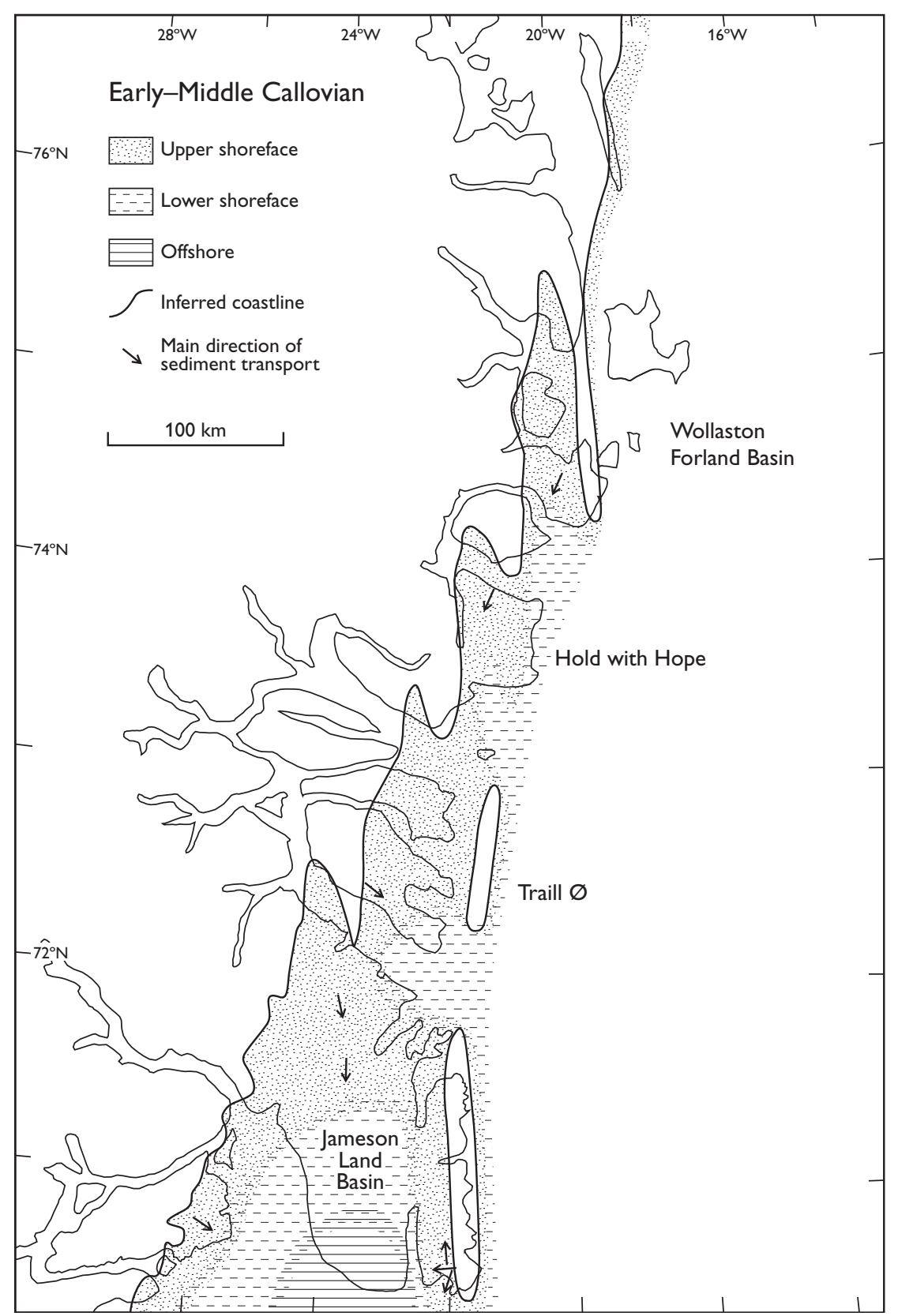

Fig. 13. Early-Middle Callovian palaeogeography and facies distribution in East Greenland. Based on Surlyk (1977), Engkilde \& Surlyk (2003), Vosgerau et al. (2004, this volume), and new data from Hold with Hope. land Basin where deposition took place on the WSW-tilted hangingwalls of major fault blocks and the elevated fault block crests formed elongated islands or peninsulas to the east (Vischer 1943; Maync 1947; Donovan 1957; Surlyk 1977; Surlyk et al. 1981; Surlyk \& Clemmensen 1983). The presence of the marine Pelion and Payer Dal Formations in the vicinity of the block crest excludes the occurrence of a major land area during Callovian and Middle Oxfordian time when the crest probably only formed elongated islands or submarine shoals.
The Hold with Hope area is thus interpreted to have formed a narrow embayment which was open for marine circulation towards the south and, during periods of high sea level, eastwards across the elevated fault block crest. Farther towards the east, the fault block was most likely limited by the continuation of the Dombjerg-Clavering Fault, which was active during the Jurassic (Maync 1947; Surlyk 1977; Stemmerik et al. 1993). The narrow head of the rift-basin occurs in an intermediate position between the Wollaston Forland and Jameson Land Basins that are situated to 
the north-east and south-west, respectively (Fig. 13). The Hold with Hope region seems to have formed a land area during the Late Callovian - Middle Oxfordian time interval whereas it was covered by sea during maximum flooding in Late Bajocian, Early-Middle Callovian and Late Oxfordian - Kimmeridgian times.

A close comparison of the Jurassic successions in the Wollaston Forland, Hold with Hope and Jameson Land basins is hindered by limited biostratigraphic control at some levels due to the scarcity of ammonites and dinoflagellate cysts in the coarse sandstone facies. It is evident, however, that the Late Callovian Middle Oxfordian hiatus in the Hold with Hope basin has not been demonstrated in the other two basins where sediments of Early-Middle Oxfordian age are well documented (Fig. 4).

The minor angular unconformity between the Pelion and Payer Dal Formations suggests that the hiatus was formed by minor tilting of fault blocks and erosion of uplifted block crests perhaps combined with eustatic sea-level falls. Sea-level falls, possibly eustatic, have been suggested to take place in Late Callovian time, at the Early-Middle Oxfordian boundary and in early Late Oxfordian time (Sahagian et al. 1996) and seem to correspond to changes in regional sea level documented in Jameson Land (Larsen \& Surlyk 2003).

The dark mudstones of the Bernbjerg Formation reflect deposition in a quiet offshore environment indicating that the influence of basin topography was overprinted by rise in relative sea level. Fault block crests to the east were finally inundated during the Kimmeridgian.

Strong fault activity occurred at the boundary between the post-Kimmeridgian and pre-Barremian successions and the fault blocks originally defining the Hold with Hope basin were split into smaller blocks, a similar tectonic development to that seen in the Wollaston Forland Basin. Comparison with the Wollaston Forland Basin suggests that this tectonic episode took place in Volgian-Valanginian time.

\section{Summary and conclusions}

A new Middle-Upper Jurassic succession is described from northern Hold with Hope. The Jurassic sediments occur on the hangingwall of small fault blocks dipping towards the WSW. The sediments are locally eroded away on the uplifted block crests, whereas they increase in thickness down-dip on the hangingwalls. The Jurassic succession is up to $360 \mathrm{~m}$ thick and is referred to the Pelion, Payer Dal and Bernbjerg Formations of Early Callovian - Early Kimmeridgian age. It overlies Lower Triassic siltstones and sandstones with a sharp boundary and is overlain by Cretaceous coarse-grained sandstones with an angular unconformity. The succession was deposited in a shoreface-offshore marine environment and reflects an overall transgression.

The Pelion Formation is c. $190 \mathrm{~m}$ thick and consists of a lower sandstone unit, 30-40 m thick, overlain by a drowning surface and sandy heteroliths and sandstones of the new Spath Plateau Member, c. $155 \mathrm{~m}$ thick. The lower sandstone unit spans the Lower Callovian C. apertum - P. koenigi Chronozones. It consists of medium to coarse-grained sandstones, which are trough cross-bedded or structureless and contain small pebbly scour-fills. The sandstones commonly form coarsening-upwards units, 6-8 $\mathrm{m}$ thick, the upper part of which are calcite cemented and contain abundant Diplocraterion habichi. The sandstones are interpreted to have been deposited in the middle to upper shoreface zone. The Spath Plateau Member is of late Early Middle Callovian, P. koenigi - P. atbleta Chron age based on ammonites and dinoflagellate cysts. It is dominated by lower-middle shoreface ripple cross-laminated sandy heteroliths and cross-bedded sandstones reflecting migration of 2-D and 3-D dunes in distributary channels and mouth bars associated with tidally influenced deltas.

The Payer Dal Formation is more than $70 \mathrm{~m}$ thick and of Middle-Late Oxfordian, C. tenuiserratum - A. glosense Chron age. It consists of cross-bedded sandstones and sandy heteroliths showing considerable lateral thickness variations and reflects progradation of tidally influenced dunes and mouth bars. It is separated from the underlying Pelion Formation by an angular unconformity representing a Late Callovian Middle Oxfordian hiatus, formed by subaerial erosion related to an eustatic sea-level fall, combined with minor tilting of fault blocks and erosion of uplifted block crests.

The Bernbjerg Formation is at least $130 \mathrm{~m}$ thick and spans the Upper Oxfordian - Lower Kimmeridgian ( $A$. glosense-P. baylei Chronozones). The basal part consists of horizontally laminated and locally cross-laminated silty fine-grained sandstones interbedded with thin wave-rippled medium- to coarse-grained sandstones and is referred to the Ugpik Ravine Member. Deposition took place in the offshore transition to lower shoreface zone. The upper part of the formation consists of structureless or horizontally laminated dark mudstones reflecting offshore deposition in an outer shelf environment. 
Deposition of the Jurassic succession on Hold with Hope took place in a narrow rift-controlled embayment as indicated by the distribution of the sediments and dominating south-westwards palaeocurrent directions in the Pelion and Payer Dal Formations. Lateral facies variations in the Spath Plateau Member indicate a decrease in palaeowater depth from west to east. The embayment was open to marine circulation to the south and probably partly to the east, where the crestal margin of a slightly westwards to south-westwards tilted block formed elongated narrow islands or submarine shoals. During the deposition of the Bernbjerg Formation, the influence of basin topography was overprinted by a rise in relative sea level and the fault block crest to the east was inundated. Towards the west, the Stensiö Plateau may have formed a separate block that was transgressed first, as indicated by the fact that the Pelion Formation is older at this locality than at Steensby Bjerg and Diener Bjerg.

The presence of an angular unconformity between the Jurassic and Cretaceous succession shows that block rotation took place in post-Kimmeridgian - pre-Barremian time. During this tectonic episode, the fault block originally defining the Hold with Hope basin was split into narrower blocks. This might have taken place in the Volgian-Valanginian as suggested by comparison with the Wollaston Forland Basin where a similar tectonic event took place during this time interval.

\section{Acknowledgements}

The present study received support from Saga Petroleum asa, and is a contribution to the project 'Resources of the sedimentary basins of North and East Greenland' supported by the Danish Research Councils. We are grateful to Lars Stemmerik and the referees Jon Gjelberg and Finn Surlyk for very useful and constructive comments. Peter Alsen and John H. Callomon are thanked for providing biostratigraphic information.

\section{References}

Alsen, P. \& Surlyk, F. 2004: Maximum Middle Jurassic transgression in East Greenland: evidence from new ammonite finds, Bjørnedal, Traill Ø. In: Stemmerik, L. \& Stouge, S. (eds): The Jurassic of North-East Greenland. Geological Survey of Denmark and Greenland Bulletin 5, 31-49 (this volume).

Alsgaard, P.C., Felt, V.L., Vosgerau, H. \& Surlyk, F. 2003: The Jurassic of Kuhn $\varnothing$, North-East Greenland. In: Ineson, J.R. \& Surlyk, F. (eds): The Jurassic of Denmark and Greenland.
Geological Survey of Denmark and Greenland Bulletin 1, 865-892.

Birkelund, T. \& Perch-Nielsen, K. 1976: Late Palaeozoic Mesozoic evolution of central East Greenland. In: Escher, A. \& Watt, W.S. (eds): Geology of Greenland, 304-339. Copenhagen: Geological Survey of Greenland.

Boersma, J.R. \& Terwindt, J.H.J. 1981: Neap-spring tide sequences of intertidal shoal deposits in a mesotidal estuary. Sedimentology 28, 151-170.

Clifton, H.E., Hunter, R.E. \& Phillips, R.L. 1971: Depositional structures and processes in the non-barred high-energy nearshore. Journal of Sedimentary Petrology 41, 651-670.

Donovan, D.T. 1957: The Jurassic and Cretaceous systems in East Greenland. Meddelelser om Grønland 155(4), 214 pp.

Elliott, T. 1974: Interdistributary bay sequences and their genesis. Sedimentology 21, 611-622.

Engkilde, M. \& Surlyk, F. 2003: Shallow marine syn-rift sedimentation: Middle Jurassic Pelion Formation, Jameson Land, East Greenland. In: Ineson, J.R. \& Surlyk, F. (eds): The Jurassic of Denmark and Greenland. Geological Survey of Denmark and Greenland Bulletin 1, 813-863.

Gjelberg, J. \& Steel, R.J. 1995: Helvetiafjellet Formation (Barremian-Aptian), Spitsbergen: characteristics of a transgressive succession. In: Steel, R.J., Felt, V., Johannessen, E.P. \& Mathieu, C. (eds): Sequence stratigraphy on the Northwest European Margin. Norwegian Petroleum Society (NPF) Special Publication 5, 571-593. Amsterdam: Elsevier.

Hunter, R.E., Clifton, H.E. \& Phillips, R.L. 1979: Depositional processes, sedimentary structures and predicted vertical sequences in barred nearshore systems, southern Oregon coast. Journal of Sedimentary Petrology 49, 711-726.

Kelly, S.R.A., Whitham, A.G., Koraini, A.M. \& Price, S.P. 1998: Lithostratigraphy of the Cretaceous (Barremian-Santonian) Hold with Hope Group, NE Greenland. Journal of the Geological Society of London 155, 993-1008.

Koch, L. 1932: Carboniferous and Triassic stratigraphy of East Greenland. Meddelelser om Grønland 83(2), 100 pp.

Koch, L. \& Haller, J. 1971: Geological map of East Greenland $72^{\circ}-76^{\circ} \mathrm{N}$. Lat. (1:250 000). Meddelelser om Grønland $\mathbf{1 8 3}$, 26 pp., 13 maps.

Larsen, M. \& Surlyk, F. 2003: Shelf-edge delta and slope deposition in the Upper Callovian - Middle Oxfordian Olympen Formation, East Greenland. In: Ineson, J.R. \& Surlyk, F. (eds): The Jurassic of Denmark and Greenland. Geological Survey of Denmark and Greenland Bulletin 1, 931-948.

Larsen, M., Piasecki, S., Preuss, T., Seidler, L., Stemmerik, L., Therkelsen, J. \& Vosgerau, H. 1998: Petroleum geological activities in East Greenland in 1997. Geology of Greenland Survey Bulletin 180, 35-42.

Maync, W. 1947: Stratigraphie der Jurabildungen Ostgrönlands zwischen Hochstetterbugten $\left(75^{\circ} \mathrm{N}\right)$ und dem Kejser Frantz Joseph Fjord $\left(73^{\circ} \mathrm{N}\right)$. Meddelelser om Grønland 132(2), 223 pp.

Maync, W. 1949: The Cretaceous beds between Kuhn Island and Cape Franklin (Gauss Peninsula), northern East Greenland. Meddelelser om Grønland 133(3), 291 pp.

Nemec, W. \& Steel, R.J. 1984: Alluvial and coastal conglomerates: their significant features and some comments on grav- 
elly mass-flow deposits. In: Koster, E.H. \& Steel, R.J. (eds): Sedimentology of gravels and conglomerates. Canadian Society of Petroleum Geologists Memoir 10, 1-31.

Piasecki, S., Larsen, M., Therkelsen, J. \& Vosgerau, H. 2004: Jurassic dinoflagellate cyst stratigraphy of Hold with Hope, North-East Greenland. In: Stemmerik, L. \& Stouge, S. (eds): The Jurassic of North-East Greenland. Geological Survey of Denmark and Greenland Bulletin 5, 73-88 (this volume).

Price, S.P. \& Whitham, A.G. 1997: Exhumed hydrocarbon traps in East Greenland: analogs for the Lower-Middle Jurassic play of Northwest Europe. American Association of Petroleum Geologists Bulletin 81, 196-221.

Sahagian, D., Pinous, O., Olferiev, A. \& Zakharov, V. 1996: Eustatic curve for the Middle Jurassic - Cretaceous based on Russian platform and Siberian stratigraphy: zonal resolution. American Association of Petroleum Geologists Bulletin 80, 1433-1458.

Stemmerik, L., Christiansen, F.G., Piasecki, S., Jordt, B., Marcussen, C. \& Nøhr-Hansen, H. 1993: Depositional history and petroleum geology of the Carboniferous to Cretaceous sediments in the northern part of East Greenland. In: Vorren, T.O., Bergsager, E., Dahl-Stamnes, Ø.A., Holter, E., Johansen, B., Lie, E. \& Lund, T.B. (eds): Arctic geology and petroleum potential. Norwegian Petroleum Society (NPF) Special Publication 5, 67-68. Amsterdam: Elsevier.

Stemmerik, L., Clausen, O.R., Korstgård, J., Larsen, M., Piasecki, S., Seidler, L., Surlyk, F. \& Therkelsen, J. 1997: Petroleum geological investigations in East Greenland: project 'Resources of the sedimentary basins of North and East Greenland'. Geology of Greenland Survey Bulletin 176, 29-38.

Surlyk, F. 1977: Stratigraphy, tectonics and palaeography of the Jurassic sediments of the areas north of Kong Oscar Fjord, East Greenland. Bulletin Grønlands Geologiske Undersøgelse 123, 56 pp.

Surlyk, F. 1978: Submarine fan sedimentation along fault scarps on tilted fault blocks (Jurassic-Cretaceous boundary, East Greenland). Bulletin Grønlands Geologiske Undersøgelse 128, 108 pp.

Surlyk, F. 1990: Timing, style and sedimentary evolution of Late Palaeozoic - Mesozoic extensional basins of East Greenland. In: Hardman R.F.P. \& Brooks, J. (eds): Tectonic events re- sponsible for Britain's oil and gas reserves. Geological Society Special Publication (London) 55, 107-125.

Surlyk, F. 1991: Sequence stratigraphy of the Jurassic - lowermost Cretaceous of East Greenland. American Association of Petroleum Geologists Bulletin 75, 1468-1488.

Surlyk, F. 2003: The Jurassic of East Greenland: a sedimentary record of thermal subsidence, onset and culmination of rifting. In: Ineson, J.R. \& Surlyk, F. (eds): The Jurassic of Denmark and Greenland. Geological Survey of Denmark and Greenland Bulletin 1, 659-722.

Surlyk, F. \& Clemmensen, L.B. 1983: Rift propagation and eustacy as controlling factors during Jurassic inshore and shelf sedimentation in northern East Greenland. Sedimentary Geology 34, 119-143.

Surlyk, F., Callomon, J.H., Bromley, R.G. \& Birkelund, T. 1973: Stratigraphy of the Jurassic - Lower Cretaceous sediments of Jameson Land and Scoresby Land, East Greenland. Bulletin Grønlands Geologiske Undersøgelse 105, 76 pp.

Surlyk, F., Clemmensen, L.B. \& Larsen, H.C. 1981: Post-Paleozoic evolution of the East Greenland continental margin. In: Kerr, J.W. \& Fergusson, A.J. (eds): Geology of the North Atlantic borderlands. Canadian Society of Petroleum Geologists Memoir 7, 611-645.

Vischer, A. 1943: Die postdevonische Tektonik von Ostgrönland zwischen $74^{\circ}$ und $75^{\circ} \mathrm{N}$ Br. Kuhn $\varnothing$, Wollaston Forland, Clavering $\varnothing$ und angrenzende Gebiete. Meddelelser om Grønland 133(1), 195 pp.

Visser, M.J. 1980: Neap-spring cycles reflected in Holocene subtidal large-scale bedform deposits: a preliminary note. Geology 8, 543-546.

Vosgerau, H., Alsen, P., Carr, I.D., Therkelsen, J., Stemmerik, L. \& Surlyk, F. 2004: Jurassic syn-rift sedimentation on a seawards-tilted fault block, Traill $\varnothing$, North-East Greenland. In: Stemmerik, L. \& Stouge, S. (eds): The Jurassic of North-East Greenland. Geological Survey of Denmark and Greenland Bulletin 5, 9-18 (this volume).

Wood, J.M. \& Hopkins, J.C. 1989: Reservoir sandstone bodies in estuarine valley fill: Lower Cretaceous Glauconitic Member, Little Bow Field, Alberta, Canada. American Association of Petroleum Geologists Bulletin 73, 1361-1382. 